\title{
WOKÓŁ ARCHIWÓW X
}

\begin{abstract}
Streszczenie. W artykule zajęto się wybranymi zagadnieniami związanymi z postępowaniami w sprawach przestępstw niewykrytych.
\end{abstract}

Słowa kluczowe: przestępstwa niewykryte, Archiwum X.

Policyjne Zespoły ds. Przestępstw Niewykrytych, zwane bardzo powszechnie Archiwami X, powstały w związku z grożącymi przedawnieniami wielu poważnych spraw, przede wszystkim o zabójstwa. Już na przełomie mileniów w sposób nieformalny w Krakowie powstała pierwsza tego typu grupa, utworzona formalnie w 2004 r. To pociągnęło za sobą powstanie dalszych tego typu grup w strukturze polskiej policji.

Wykrywanie spraw z przeszłości wiąże się z daleko idącą specyfiką, bowiem w tym przypadku szczególnie trudne jest np. powiązanie śladów daktyloskopijnych czy biologicznych, które dzięki rozwojowi techniki możemy badać w znacznie większym stopniu niż przed laty. Wyraźnie utrudnione jest także zastosowanie dowodów z osobowych źródeł dowodowych, ponieważ upływ czasu wpływa na obraz pamięciowy zaistniałego zdarzenia. Podobnie znaczną specyfiką charakteryzuje się wykrywanie przestępczości przeciwko zabytkom.

Bardzo interesującym i ważnym z punktu widzenia praktyki zagadnieniem, nie tylko na gruncie postępowań karnych, jest poszukiwanie zwłok ludzkich. Niejednokrotnie zdarza się, iż nawet sam sprawca podczas przesłuchania wskazuje organom ścigania miejsce ukrycia zwłok, ale z uwagi np. na upływ czasu, nie jest w stanie go precyzyjnie wskazać, co niejednokrotnie uniemożliwia bądź utrudnia ich odnalezienie. Współcześnie wykorzystuje się wiele metod, np. georadar, detektory metalu, magnetometry czy detektory metali, a także psy tropiące zwłoki, co znacznie zwiększa szanse na odnalezienie zwłok i szczątków ludzkich. W zakresie nowych możliwości ciekawym zagadnieniem jest też wykorzystywanie informacji udostępnianych w Internecie, niejednokrotnie przez samych przestępców.

Bardzo duże kontrowersje budzą sprawy nie do końca wyjaśnionych śmierci takich osób, jak S. Jasienin czy M. Monroe, a także morderstwa dokonywane przez „Kubę Rozpruwacza”. Wokół nich krąży szereg wersji, formułowane są

* Uniwersytet Łódzki, Wydział Prawa i Administracji, Katedra Postępowania Karnego i Kryminalistyki, zbigniew.wardak@gmail.com. 
także teorie spiskowe. Niekiedy zaniedbania czy brak wystarczająco transparentnego działania organów ścigania powodują, że takie sprawy są głośne przez bardzo długi czas.

Dyskutując na temat spraw niewyjaśnionych, często powraca problem, czy w sprawach najpoważniejszych, takich jak zabójstwa, powinno obowiązywać przedawnienie czy też, wzorem np. zbrodni ludobójstwa, sprawy te powinny być nieprzedawnialne. Wiele racji przemawia zarówno za jednym, jak i za drugim rozwiązaniem. $Z$ jednej strony wskazuje się bowiem na tzw. łagodzący upływ czasu, trudności dowodowe czy brak możliwości realizacji celów kary, a z drugiej - zauważa się dyskusyjność tych argumentów oraz konieczność zaniechania ścigania ważnych spraw bulwersujących opinię publiczną. Uznając ważkie racje za nieprzedawnialnością, należy pamiętać, że gdyby nie grożący upływ terminu przedawnienia $\mathrm{w}$ niektórych sprawach, zapewne nie doszłoby do powołania takich grup, jak tzw. Archiwa X. Istnieje poza tym obawa, iż należałoby wnikliwie badać, a następnie umarzać sprawy, np. z uwagi na niewykrycie sprawcy, w sytuacji gdy ze względu na upływ czasu i długość życia ludzkiego, sprawca taki zapewne od dawna nie żyje.

W przypadku Policyjnych Zespołów ds. Przestępstw Niewykrytych nasuwa się pewna refleksja. Takie grupy i sposoby ich działania są objęte tajemnicą, a potoczna nazwa Archiwa X wskazuje na ponadnaturalną specyfikę postępowania w prowadzonych przez nie sprawach. Oczywiście w pewnym zakresie, zwłaszcza w odniesieniu do niektórych metod operacyjno-rozpoznawczych, działania policyjne muszą być otoczone tajemnicą. Jednakże w pozostałym zakresie należy „odmitologizować” działalność takich zespołów, ponieważ wzajemne zrozumienie jest warunkiem skutecznej współpracy różnych pionów policyjnych. Należy zatem podkreślić znaczenie działań naukowych i edukacyjnych, zmierzających do zbadania specyfiki działalności w sprawach niewykrytych, a także rozpowszechnienia tej wiedzy w organach ścigania, wymiarze sprawiedliwości oraz wśród studentów prawa - przyszłych sędziów, prokuratorów i policjantów ${ }^{1}$.

\section{Zbigniew Wardak}

\section{AROUND X ARCHIVES}

Abstract. The article deals with on selected issues related to proceedings in undetected crimes. Keywords: undetected offences, Police X Archives.

${ }^{1} \mathrm{Na}$ Wydziale Prawa i Administracji Uniwersytetu Łódzkiego odbyły się dwie ogólnopolskie konferencje poświęcone tzw. Policyjnym Archiwom X w dniach 25-26 marca 2015 r. oraz 15-16 grudnia 2016 r.; planowana jest też kolejna konferencja w dniach 28-29 września 2018 r. 